\title{
Role of Somatostatin Receptors in Normal and Tumoral Pituitary Corticotropic Cells
}

\author{
Leo J. Hofland Steven W.J. Lamberts Richard A. Feelders \\ Department of Internal Medicine, Division of Endocrinology, Erasmus MC, Rotterdam, The Netherlands
}

\section{Key Words}

Somatostatin receptor $\cdot$ Adenoma $\cdot$ Pituitary •

Adrenocorticotropic hormone $\cdot$ Cortisol $\cdot$ Glucocorticoids .

Corticotrope

\begin{abstract}
Normal and tumoral pituitary corticotropic cells express sst ${ }_{2}$ and $\mathrm{sst}_{5}$, of which $\mathrm{sst}_{5}$ is the predominantly expressed receptor subtype. Somatostatin (SS) inhibits pituitary adrenocorticotropin hormone $(\mathrm{ACTH})$ secretion in vitro, but the sensitivity to SS is strongly regulated by glucocorticoids. In pathological conditions of a low endogenous cortisol level, i.e. in patients with adrenal insufficiency and in patients with Nelson's syndrome, $\mathrm{SS}$ and sst $_{2}$-preferring SS analogs (SSA), such as octreotide, are able to lower circulating ACTH and cortisol levels. On the other hand, sst ${ }_{2}$-preferring SSA seem not effective in lowering ACTH and cortisol levels in patients with untreated Cushing's disease (CD), in which circulating cortisol levels are high. This is likely due to the downregulation of sst $_{2}$ receptors by glucocorticoids. sst $_{5}$ receptor expression is more resistant to the inhibitory effect of glucocorticoids. In recent years, novel sst subtype-selective and universal SSA have been developed. In particular, SSA with a high sst $_{5^{-}}$ binding affinity are potent inhibitors of ACTH secretion by pituitary corticotropic adenoma cells. This knowledge has
\end{abstract}

initiated clinical trials evaluating the efficacy of these novel SSA in patients with $C D$, with the aim to lower circulating ACTH and cortisol levels by targeting multiple ssts on the corticotropic adenoma cells. In this minireview, the effects of SS in the regulation of normal and tumoral ACTH secretion, the role of sst subtypes involved herein, as well as the potentials of novel SSA in the treatment of patients with recurrent or persisting CD are discussed. Copyright $\Theta 2010$ S. Karger AG, Basel

\section{Introduction}

Somatostatin (SS) was originally characterized as a hypothalamic peptide with a direct inhibitory activity on the secretion of growth hormone $(\mathrm{GH})$ by the anterior pituitary gland [1]. Since this original discovery, numerous studies have established that SS exists in two molecular forms in the circulation, i.e. a 14- and a 28 -amino acid cyclic peptide, named SS-14 and SS-28, respectively. Both peptides have a widespread biological activity due to the presence of SS receptors (sst) in many organ systems, including the brain, the pituitary gland, the gastrointestinal tract, pancreas and adrenals $[2,3]$. ssts are seventransmembrane receptors that are coupled to G-proteins and of which five subtypes, named $\mathrm{sst}_{1}, \mathrm{sst}_{2}, \mathrm{sst}_{3}, \mathrm{sst}_{4}$ and

\section{KARGER}

Fax +41613061234

E-Mail karger@karger.ch

www.karger.com
(C) 2010 S. Karger AG, Basel

0028-3835/10/0925-0011\$26.00/0

Accessible online at:

www.karger.com/nen
Leo J. Hofland

Department of Internal Medicine, Division of Endocrinology

Room Ee530b, Dr. Molewaterplein 50

NL-3015 GE Rotterdam (The Netherlands)

Tel. +31 10703 4633, Fax +31 10703 5430, E-Mail l.hofland@erasmusmc.nl 
Table 1. Binding affinities ( $\mathrm{IC}_{50}$ in $\mathrm{nM}$ ) of the current clinically used SS analogs, octreotide and lanreotide, and of the universal SS ligand pasireotide to the human sst subtypes

\begin{tabular}{llllll}
\hline Compound & sst & sst $_{2}$ & sst $_{3}$ & sst $_{4}$ & sst $_{5}$ \\
\hline SS-14 & $0.9-2.3^{\mathrm{a}-\mathrm{d}}$ & $0.2-0.3^{\mathrm{a}-\mathrm{d}}$ & $0.6-1.4^{\mathrm{a}-\mathrm{d}}$ & $1.5-1.8^{\mathrm{a}-\mathrm{d}}$ & $0.3-1.4^{\mathrm{a}-\mathrm{d}}$ \\
Octreotide & $280-1,140^{\mathrm{a}-\mathrm{e}}$ & $0.4-0.6^{\mathrm{a}-\mathrm{e}}$ & $7.1-34.5^{\mathrm{a}-\mathrm{e}}$ & $>1,000^{\mathrm{a}-\mathrm{e}}$ & $6.3-7.0^{\mathrm{a}-\mathrm{d}}$ \\
Lanreotide & $180-2,330^{\mathrm{a}-\mathrm{e}}$ & $0.5-0.8^{\mathrm{a}-\mathrm{e}}$ & $14-107^{\mathrm{a}-\mathrm{e}}$ & $230-2,100^{\mathrm{a}-\mathrm{e}}$ & $5.2-17^{\mathrm{a}-\mathrm{e}}$ \\
Pasireotide & $9.3^{\mathrm{c}}$ & $1.0^{\mathrm{c}}$ & $1.5^{\mathrm{c}}$ & $>100^{\mathrm{c}}$ & $0.2^{\mathrm{c}}$ \\
\hline
\end{tabular}

Data are derived from references ${ }^{\mathrm{a}}[36],{ }^{\mathrm{b}}[6],{ }^{\mathrm{c}}[37],{ }^{\mathrm{d}}[38],{ }^{\mathrm{e}}[39]$.

sst $_{5}$, have been identified. On the basis of structural and pharmacological characteristics, two subclasses have been identified. To one class of sst, consisting of sst $_{2}$, sst $_{3}$ and sst $_{5}$, structural SS analogs (SSA), such as octreotide and lanreotide, bind with high affinity, whereas these SSA do not bind to the other class of sst, consisting of sst $_{1}$ and $\mathrm{sst}_{4}$ (table 1) [4]. Among the multiple physiological effects of SS is its potent inhibitory effect on pituitary hormone secretion $[2,3]$. SS is considered as a physiological regulator of $\mathrm{GH}$ secretion. In vitro, the peptide inhibits the secretion of $\mathrm{GH}$, prolactin (PRL), thyroid stimulating hormone (TSH), as well as adrenocorticotropin hormone (ACTH) by rat anterior pituitary cells, although its effects are strongly influenced by the respective physiological feedback hormones [5]. In human fetal pituitary cell cultures, SS inhibits the secretion of GH, TSH and PRL, whereas the release of ACTH and luteinizing hormone (LH) is only modestly influenced [6]. The effects of SS on normal and tumoral ACTH secretion are strongly regulated by glucocorticoids, representing the physiological feedback system [5].

\section{Role of Somatostatin Receptors in Normal Corticotropic Cells}

In normal rat corticotropes, all five sst colocalize with ACTH-expressing cells [7]. In another study, it was demonstrated that $\mathrm{sst}_{5} \mathrm{mRNA}$ is expressed in $38 \%$ of corticotropes, whereas the expression of $s^{2} t_{2} \mathrm{mRNA}$ is found in only $3 \%$ of the corticotropic cell population [8]. By immunohistochemistry, $<60 \%$ and $10-20 \%$ of rat corticotropic cells express detectable $s \mathrm{At}_{2 \mathrm{~A}}$ and $\mathrm{sst}_{5}$ at the protein level, respectively [9]. In vitro, SS does not inhibit basal and $\mathrm{CRH}$-induced ACTH release by normal rat anterior pituitary cells $[10,11]$, whereas $\mathrm{CRH}$ - and vasopressininduced ACTH release is inhibited in cultured pituitary cells from long-term adrenalectomized rats [12]. In serum-deprived or in rat pituitary cells pretreated with the glucocorticoid receptor-blocking compound RU-38486 in vitro, SS inhibits CRH-stimulated ACTH secretion, but not in serum cultured cells. Moreover, pretreatment with dexamethasone abolished the inhibitory effect of SS on ACTH release [5]. Therefore, it can be concluded that SS is able to inhibit CRH-induced ACTH secretion by rat pituitary cells in vitro, but primarily in the absence of glucocorticoids.

In humans, systemic SS infusion does not inhibit basal or stimulated ACTH secretion [13-15]. On the other hand, in patients with adrenal insufficiency, SS infusion lowers circulating ACTH and cortisol levels [16]. These latter data again suggest the importance of the endogenous cortisol level in the regulation of the inhibitory effects of SS on ACTH secretion by the anterior pituitary gland. In vivo evidence in rats shows the importance of both $\mathrm{sst}_{2}$ and $\mathrm{sst}_{5}$ receptors in the regulation of $\mathrm{ACTH}$ secretion. A 1-hour pretreatment of rats with $10 \mu \mathrm{g} / \mathrm{kg}$ pasireotide (targeting $\mathrm{sst}_{2}$, sst $_{3}$ and sst $_{5}$ receptors) inhibited circulating ACTH and corticosterone levels by 51 and $27 \%$, respectively, whereas octreotide ( sst $_{2}$-preferring SSA) was significantly less potent ( $34 \%$ and no inhibition, respectively) at this dosage [17]. These data suggest that the combined activation of both sst ${ }_{2}$ and sst $_{5}$ receptors in corticotropic cells results in a more potent suppression of ACTH secretion compared with the selective targeting of sst $_{2}$ alone.

In conclusion, endogenous glucocorticoid levels modulate the effects of SS on ACTH secretion by normal pituitary corticotropes. SS has an inhibitory effect on pituitary ACTH secretion, particularly when cortisol levels are low. 


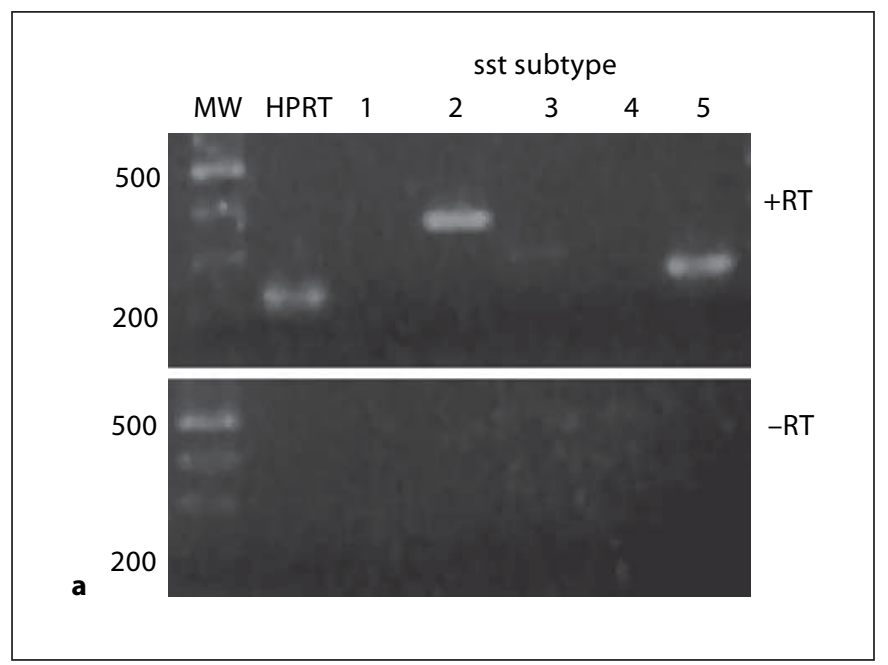

Fig. 1. a Expression of $s_{2} t_{2}$ and sst $_{5}$ subtypes in mouse AtT20 pituitary tumor cells. Poly $\mathrm{A}^{+}$mRNA was reverse transcribed and cDNA was amplified by PCR. PCR products of the $s t_{1-5}$ were separated on $1 \%$ agarose gel and stained with ethidium bromide. Upper panel: cDNA synthesis in the presence of reverse transcriptase (+RT); lower panel: negative control of cDNA synthesis in the absence of RT (-RT) to exclude the presence of genomic DNA contamination. Only bands of $\mathrm{sst}_{2}, \mathrm{sst}_{3}$ and $\mathrm{sst}_{5}$ PCR products with the expected molecular weight $(\mathrm{MW})$ were detected. HPRT:

\section{Role of Somatostatin Receptors in Corticotropic Adenoma Cells}

Already in 1981, Richardson and Schonbrunn [18] showed the presence of SS-binding sites in the ACTHsecreting AtT20/D16V mouse corticotropic tumor cell line and demonstrated inhibition of ACTH secretion by SS in vitro [18]. Since the cloning and characterization of the five sst, also the expression of these sst subtypes in human corticotropic adenomas has been evaluated. Human corticotropic adenomas show a predominant expression of $s t_{5}$ mRNA, whereas the majority of adenomas express $s_{2} t_{2}$ mRNA as well. Compared with sst $_{2}$ mRNA, sst ${ }_{5}$ mRNA expression has been reported to be approximately 5 - to 10-fold higher [19-23]. Limited studies have evaluated the expression of sst $_{2}$ and sst $_{5}$ receptors at the protein level. Batista et al. [19] showed that sst $_{5}$ had the highest immunohistochemistry score, compared with $s_{1} \mathrm{~s}_{1}, \mathrm{sst}_{2}, \mathrm{sst}_{3}$ and $\mathrm{sst}_{4}$ protein expression, in $83 \%$ of a series of 13 corticotropic adenomas, while in another small series of three corticotropic adenomas, Hassaneen et al. [24] showed an absence of sst ${ }_{5}$ immunostaining. The reason for these discordant results is unclear, but may be the result of the use of different antibodies. Coexpression

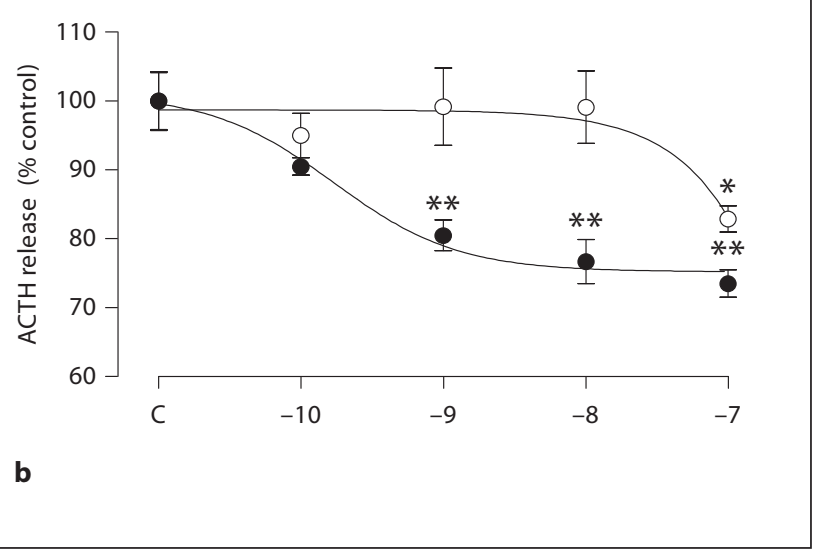

house-hold keeping gene hypoxantine-phosphoribosyl-transferase. b Dose-dependent effect of SOM230 (pasireotide) and octreotide (OCT) on basal ACTH release by mouse AtT20 pituitary tumor cells. AtT20 cells were incubated during $72 \mathrm{~h}$ without or with increasing concentrations of OCT (open circles) or SOM230 (closed circles) after which the medium was collected for ACTH determination. Values are expressed as the \% of control (untreated) cells. ${ }^{*} \mathrm{p}<0.05$ and ${ }^{* *} \mathrm{p}<0.01$ vs. control. Adapted with permission from Hofland et al. [22].

of $s t_{1}$ receptors has been reported in only a proportion of corticotropic adenomas [20-23]. Interestingly, in silent corticotropic adenomas a considerable higher sst $_{1}$ and $\mathrm{sst}_{2}$, but lower $\mathrm{sst}_{5}$ mRNA expression was found, compared with corticotropic adenomas causing Cushing's disease (CD) [20].

In primary cultures of corticotropic adenomas the universal SSA pasireotide (high sst $_{2^{-}}$, sst $_{3^{-}}$and sst $_{5}$-binding affinity) was significantly more potent in inhibiting ACTH secretion, compared with the sst $_{2}$-preferring SSA octreotide [22]. Following a 72-h incubation, octreotide $(10 \mathrm{nM})$ inhibited ACTH secretion by $28 \%$ in only 1 of 5 cultures, whereas pasireotide $(10 \mathrm{nM})$ induced significant suppression of ACTH secretion in 3 of 5 cultures (30$40 \%$ suppression) [22]. Moreover, Batista et al. [19] demonstrated significant suppression of ACTH secretion in 5 of 6 cultures (23-56\% suppression). In AtT20 corticotropic adenoma cells, both pasireotide, as well as sst $_{5}$-selective SSA were more potent inhibitors of basal and CRH-induced ACTH secretion, compared with sst ${ }_{2}$-preferring SSA (fig. 1) [22, 25]. Figure 1a shows that AtT20/ D16V cells selectively express sst ${ }_{2}$ and sst $_{5}$ mRNA. Moreover, pasireotide inhibits ACTH secretion with an $\mathrm{IC}_{50}$ of $0.2 \mathrm{nM}$, whereas octreotide induced a significant suppres- 


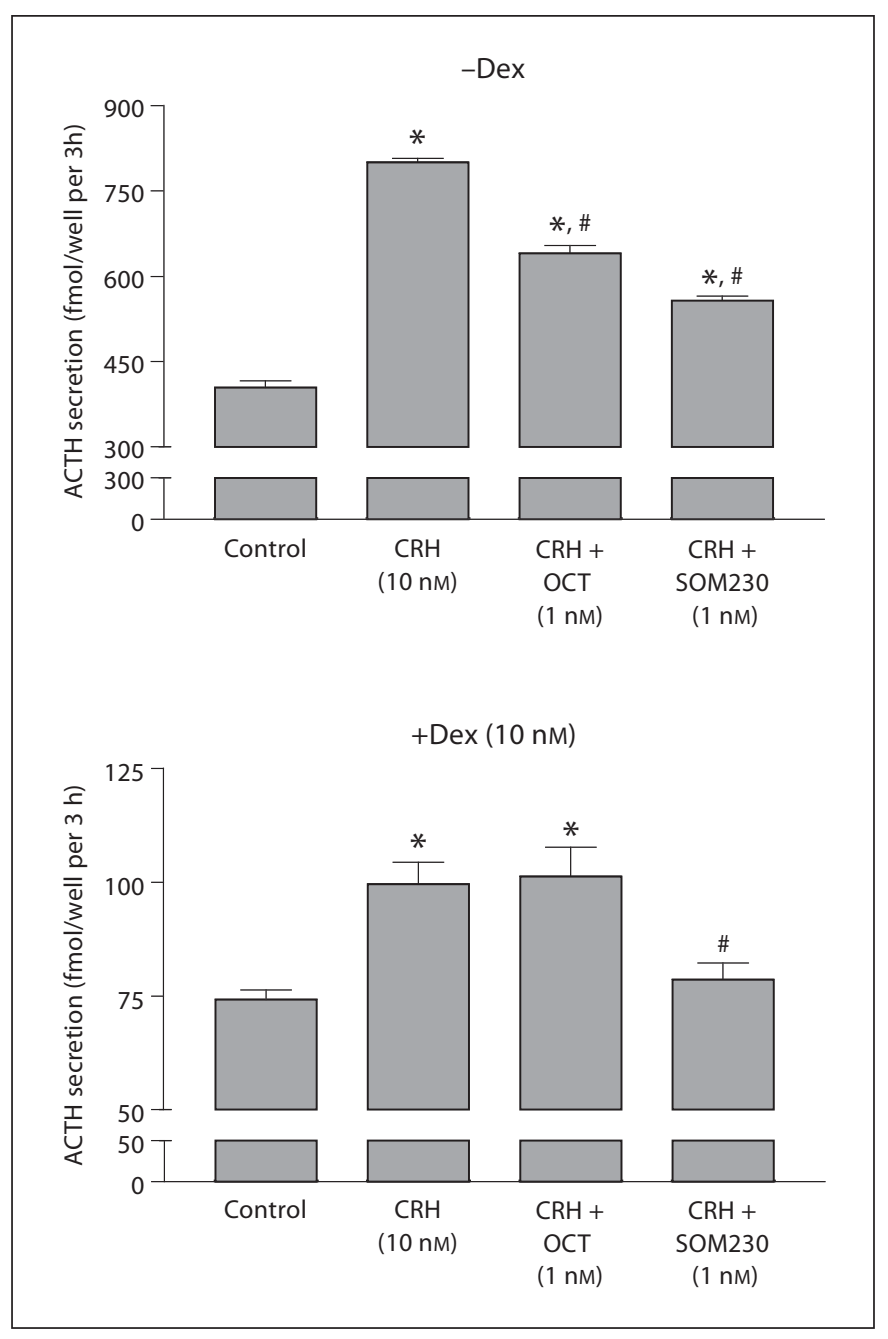

Fig. 2. Effect of glucocorticoids on octreotide (OCT) and SOM 230 (pasireotide) mediated inhibition of $\mathrm{CRH}$-stimulated ACTH release by mouse AtT20 pituitary adenoma cells. AtT20 cells were preincubated during $48 \mathrm{~h}$ without or with $10 \mathrm{nM}$ dexamethasone (Dex). After $48 \mathrm{~h}$, the medium was refreshed and the cells were incubated for $3 \mathrm{~h}$ in the absence or presence of Dex, CRH (10 nM) and OCT (1 nM) or SOM230 (1 nM) after which the medium was collected for ACTH determination. ${ }^{*} \mathrm{p}<0.01$ vs. control, ${ }^{*} \mathrm{p}<$ 0.01 vs. $\mathrm{CRH}$ alone. Adapted with permission from Hofland et al. [22].

sion of ACTH release only at $100 \mathrm{nM}$. These effects clearly indicate that ACTH secretion is inhibited in a 'sst ${ }_{5}$-like' fashion, in agreement with the binding affinities of pasireotide and octreotide to $s t_{2}$ and sst $_{5}$ (table 1). Recently, it was shown that $\mathrm{sst}_{5}$ determines both the short- and long-term enhanced action of pasireotide in corticotropic tumor cells, whereas the ligand action on $\mathrm{sst}_{2}$ is negligible. Short-term exposure to pasireotide caused prolonged signaling in terms of forskolin- or CRH-induced cAMP accumulation, in contrast to SS-14 and sst ${ }_{2}$-selective agonists that induced a postwithdrawal cAMP rebound [26].

In conclusion, sst $_{5}$ receptors are expressed at a significant level in corticotropic adenomas and seem a target to lower tumoral ACTH secretion with sst ${ }_{5}$-preferring SSA.

\section{Regulation of Somatostatin Receptor Expression by Glucocorticoids}

The observation that SS and the sst $_{2}$-preferring SSA octreotide do not inhibit circulating ACTH levels in patients with untreated $\mathrm{CD}[27,28]$, in combination with the inhibitory effects of SS on ACTH levels in patients with adrenal insufficiency (Addison's disease) [16] and Nelson's syndrome [27,29], suggests that glucocorticoids have a negative regulatory role on the expression of sst receptors, particularly $s s t_{2}$, and indicates that SS is a potent inhibitor of ACTH secretion in patients with elevated ACTH levels due to a lack in steroid feedback. Downregulation of SS-binding sites on AtT20 corticotropic tumor cells was previously shown by Schonbrunn [30]. More recently, we found that dexamethasone treatment of AtT20 cells induced a significant suppression of sst $_{2}$ mRNA expression, whereas $\mathrm{sst}_{5} \mathrm{mRNA}$ expression was not significantly affected [25]. Moreover, the number of binding sites for the sst $_{2}$-preferring SSA octreotide was lowered by $72 \%$ by dexamethasone treatment, whereas the total number of binding sites for SS-14 was lowered only by $17 \%$. These data suggest that the sst $_{5}$ protein expression, compared with $\mathrm{sst}_{2}$, is more resistant to downregulation by glucocorticoids. The functional consequence of this effect was further underlined by the observation that the effects of octreotide on CRH-induced ACTH secretion by At 20 cells were abolished by dexamethasone treatment, whereas pasireotide potently suppressed $\mathrm{CRH}$-induced ACTH secretion, even in the presence of $10 \mathrm{nM}$ dexamethasone (fig. 2) [25].

In conclusion, sst $_{2}$ receptor expression on corticotropic adenoma cells is downregulated by glucocorticoids, whereas sst ${ }_{5}$ receptor expression is less sensitive to this downregulation. These data may form an explanation for the low $s^{2} t_{2}$ and relatively high $s t_{5}$ expression levels in corticotropic adenomas of patients with CD. Moreover, these observations may explain the lack of efficacy of sst ${ }_{2}$-preferring SSA in patients with CD and suggest an enhanced potency of $s^{2} t_{2}-$ sst $_{5}$ targeting SSA on ACTH secretion by corticotropic adenomas. 


\section{Outlook}

The observation that $\mathrm{sst}_{5}$ receptors are expressed at significant levels in human corticotropic adenomas, together with the more important role of $\mathrm{sst}_{5}$, compared with $\mathrm{sst}_{2}$, in the regulation of tumoral ACTH secretion, has initiated clinical trials testing the efficacy of the universal SSA pasireotide in patients with CD. Promising results of a first phase II clinical study with pasireotide in $\mathrm{CD}$ have been recently reported [31]. On the basis of the potent inhibitory effect of glucocorticoids on $\mathrm{sst}_{2}$ expression in corticotropic adenoma cells, it can be hypothesized that lowering of circulating cortisol levels in patients with CD results in an upregulation of sst $_{2}$ expression on the corticotropic adenoma, thereby further contributing to an ACTH-lowering effect of sst $_{2}-$ sst $_{5}$ targeting SSA. This lowering of circulating cortisol in patients with recurrent or persisting CD may be achieved with sst ${ }_{2}-$ sst $_{5}$ targeting SSA, but also with dopamine D2 agonists, such as cabergoline, or with drugs inhibiting cortisol production at the adrenal level, such as ketoconazole. Corticotropic adenomas express D2 in about 70\% of the cases [32] and cabergoline induces long-term normalization in approximately $40 \%$ of patients with CD unsuccessfully treated by surgery [33]. D2 mRNA receptor expression in corticotropic adenomas is significantly higher compared to $s t_{5}$ and $s t_{2}$ mRNA expression [21, 23]. Interestingly, unlike $s t_{2}$, but comparable to $s t_{5}, \mathrm{D} 2$ receptor expression seems not under the negative regulatory control by glucocorticoids [34]. We recently found that biochemical remission can be achieved in $90 \%$ of patients with $\mathrm{CD}(\mathrm{n}=17)$ with pasireotide monotherapy (29\%), with combined pasireotide-cabergoline treatment (in an additional 24\%) and in another 35\% with triple therapy with pasireotide, cabergoline and ketoconazole [35, and this issue]. Therefore, a future approach for medical treatment of recurrent or persistent $\mathrm{CD}$ may involve combination therapy with drugs that have additive or potentiating effects.

\section{Disclosure Statement}

The authors have nothing to disclose.

\section{References}

1 Brazeau P, Vale W, Burgus R, Ling N, Butcher M, Rivier J, Guillemin R: Hypothalamic polypeptide that inhibits the secretion of immunoreactive pituitary growth hormone. Science 1973;179:77-79.

$\checkmark 2$ Patel YC: Somatostatin and its receptor family. Front Neuroendocrinol 1999;20:157-198.

$\checkmark 3$ Lamberts SW, van der Lely AJ, de Herder WW, Hofland LJ: Octreotide. N Engl J Med 1996;334:246-254.

4 Weckbecker G, Lewis I, Albert R, Schmid HA, Hoyer D, Bruns C: Opportunities in somatostatin research: biological, chemical and therapeutic aspects. Nat Rev Drug Discov 2003;2:999-1017.

5 Lamberts SW, Zuyderwijk J, den Holder F, van Koetsveld P, Hofland L: Studies on the conditions determining the inhibitory effect of somatostatin on adrenocorticotropin, prolactin and thyrotropin release by cultured rat pituitary cells. Neuroendocrinology 1989;50:44-50.

6 Shimon I, Taylor JE, Dong JZ, Bitonte RA, Kim S, Morgan B, Coy DH, Culler MD, Melmed S: Somatostatin receptor subtype specificity in human fetal pituitary cultures. Differential role of sstr2 and sstr 5 for growth hormone, thyroid-stimulating hormone, and prolactin regulation. J Clin Invest 1997; 99:789-798.
7 O’Carroll AM, Krempels K: Widespread distribution of somatostatin receptor messenger ribonucleic acids in rat pituitary. Endocrinology 1995;136:5224-5227.

-8 Day R, Dong W, Panetta R, Kraicer J, Greenwood MT, Patel YC: Expression of mRNA for somatostatin receptor (sstr) types 2 and 5 in individual rat pituitary cells. A double labeling in situ hybridization analysis. Endocrinology 1995;136:5232-5235.

-9 Mezey E, Hunyady B, Mitra S, Hayes E, Liu Q, Schaeffer J, Schonbrunn A: Cell specific expression of the sst $2 \mathrm{a}$ and sst 5 somatostatin receptors in the rat anterior pituitary. Endocrinology 1998;139:414-419.

10 Brown MR, Rivier C, Vale W: Central nervous system regulation of adrenocorticotropin secretion: role of somatostatins. Endocrinology 1984;114:1546-1549.

11 Kraicer J, Gajewski TC, Moor BC: Release of pro-opiomelanocortin-derived peptides from the pars intermedia and pars distalis of the rat pituitary: effect of corticotrophin-releasing factor and somatostatin. Neuroendocrinology 1985;41:363-373.

12 Voight KH, Fehm HL, Lang RE, Walter R: The effect of somatostatin and of prolylleucyl-glycinamide (mif) on ACTH release in dispersed pituitary cells. Life Sci 1977;21: 739-745.
13 Volpi R, Chiodera P, Capretti L, Caiazza A, Caffarri G, Magotti MG, Boni S, Coiro V: Inhibition by somatostatin of the growth hormone, but not corticotropin response to angiotensin II in normal men. Horm Res 1996; 45:269-272.

-14 Stafford PJ, Kopelman PG, Davidson K, McLoughlin L, White A, Rees LH, Besser GM, Coy DH, Grossman A: The pituitaryadrenal response to crf- 41 is unaltered by intravenous somatostatin in normal subjects. Clin Endocrinol (Oxf) 1989;30:661-666.

$\checkmark 15$ Broglio F, Arvat E, Benso A, Gottero C, Prodam F, Grottoli S, Papotti M, Muccioli G, van der Lely AJ, Deghenghi R, Ghigo E: Endocrine activities of cortistatin-14 and its interaction with GHRH and ghrelin in humans. J Clin Endocrinol Metab 2002;87:3783-3790.

$\checkmark 16$ Fehm HL, Voigt KH, Lang R, Beinert KE, Raptis S, Pfeiffer EF: Somatostatin: a potent inhibitor of ACTH-hypersecretion in adrenal insufficiency. Klin Wochenschr 1976;54: 173-175.

17 Silva AP, Schoeffter P, Weckbecker G, Bruns C, Schmid HA: Regulation of CRH-induced secretion of ACTH and corticosterone by SOM230 in rats. Eur J Endocrinol 2005; 153:R7-R10. 
18 Richardson UI, Schonbrunn A: Inhibition of adrenocorticotropin secretion by somatostatin in pituitary cells in culture. Endocrinology 1981;108:281-290.

19 Batista DL, Zhang X, Gejman R, Ansell PJ, Zhou Y, Johnson SA, Swearingen B, HedleyWhyte ET, Stratakis CA, Klibanski A: The effects of SOM230 on cell proliferation and adrenocorticotropin secretion in human corticotroph pituitary adenomas. J Clin Endocrinol Metab 2006;91:4482-4488.

-20 Tateno T, Kato M, Tani Y, Oyama K, Yamada S, Hirata Y: Differential expression of somatostatin and dopamine receptor subtype genes in adrenocorticotropin (ACTH)-secreting pituitary tumors and silent corticotroph adenomas. Endocr J 2009;56:579-584.

-21 Saveanu A, Jaquet P: Somatostatin-dopamine ligands in the treatment of pituitary adenomas. Rev Endocr Metab Disord 2009; 10:83-90.

22 Hofland LJ, van der Hoek J, Feelders R, van Aken MO, van Koetsveld PM, Waaijers M, Sprij-Mooij D, Bruns C, Weckbecker G, de Herder WW, Beckers A, Lamberts SW: The multi-ligand somatostatin analogue SOM230 inhibits acth secretion by cultured human corticotroph adenomas via somatostatin receptor type 5. Eur J Endocrinol 2005; 152:645-654.

$\checkmark 23$ de Bruin C, Pereira AM, Feelders RA, Romijn JA, Roelfsema F, Sprij-Mooij DM, van Aken MO, van der Lelij AJ, de Herder WW, Lamberts SW, Hofland LJ: Coexpression of dopamine and somatostatin receptor subtypes in corticotroph adenomas. J Clin Endocrinol Metab 2009;94:1118-1124.

24 Hassaneen W, Cahill DP, Fuller GN, Levine NB: Immunohistochemical detection of somatostatin receptor subtype 5 (SSTR-5) in Cushing adenoma. J Neurooncol 2010;98: 151-152.
25 van der Hoek J, Waaijers M, van Koetsveld PM, Sprij-Mooij D, Feelders RA, Schmid HA, Schoeffter P, Hoyer D, Cervia D, Taylor JE, Culler MD, Lamberts SW, Hofland LJ: Distinct functional properties of native somatostatin receptor subtype 5 compared with subtype 2 in the regulation of ACTH release by corticotroph tumor cells. Am J Physiol Endocrinol Metab 2005;289:E278E287.

26 Ben-Shlomo A, Schmid H, Wawrowsky K, Pichurin O, Hubina E, Chesnokova V, Liu NA, Culler M, Melmed S: Differential ligand-mediated pituitary somatostatin receptor subtype signaling: implications for corticotroph tumor therapy. J Clin Endocrinol Metab 2009;94:4342-4350.

27 Lamberts SW, Uitterlinden P, Klijn JM: The effect of the long-acting somatostatin analogue sms 201-995 on ACTH secretion in Nelson's syndrome and Cushing's disease. Acta Endocrinol (Copenh) 1989;120:760766.

28 Ambrosi B, Bochicchio D, Ferrario R, Colombo P, Faglia G: Screening tests for Cushing's syndrome. Clin Endocrinol (Oxf) 1990; 33:809-811.

29 Tyrrell JB, Lorenzi M, Gerich JE, Forsham $\mathrm{PH}$ : Inhibition by somatostatin of ACTH secretion in Nelson's syndrome. J Clin Endocrinol Metab 1975;40:1125-1127.

30 Schonbrunn A: Glucocorticoids down-regulate somatostatin receptors on pituitary cells in culture. Endocrinology 1982;110:11471154.

-31 Boscaro M, Ludlam WH, Atkinson B, Glusman JE, Petersenn S, Reincke M, Snyder P, Tabarin A, Biller BM, Findling J, Melmed S, Darby CH, Hu K, Wang Y, Freda PU, Grossman AB, Frohman LA, Bertherat J: Treatment of pituitary-dependent cushing's disease with the multireceptor ligand somatostatin analog pasireotide (som230): a multicenter, phase II trial. J Clin Endocrinol Metab 2009;94:115-122.

-32 Pivonello R, Ferone D, de Herder WW, Kros JM, De Caro ML, Arvigo M, Annunziato L, Lombardi G, Colao A, Hofland LJ, Lamberts SW: Dopamine receptor expression and function in corticotroph pituitary tumors. J Clin Endocrinol Metab 2004;89:2452-2462.
33 Pivonello R, De Martino MC, Cappabianca P, De Leo M, Faggiano A, Lombardi G, Hofland LJ, Lamberts SW, Colao A: The medical treatment of Cushing's disease: effectiveness of chronic treatment with the dopamine agonist cabergoline in patients unsuccessfully treated by surgery. J Clin Endocrinol Metab 2009;94:223-230.

>34 de Bruin C, Feelders RA, Waaijers AM, van Koetsveld PM, Sprij-Mooij DM, Lamberts SW, Hofland LJ: Differential regulation of human dopamine D2 and somatostatin receptor subtype expression by glucocorticoids in vitro. J Mol Endocrinol 2009;42:4756.

35 Feelders RA, de Bruin C, Pereira AM, Romijn JA, Netea-Maier RT, Hermus AR, Zelissen $\mathrm{PM}$, de Jong $\mathrm{FH}$, van der Lely AJ, de Herder WW, Hofland LJ, Lamberts SWJ: Stepwise medical treatment of Cushing's disease with pasireotide mono- or combination therapy with cabergoline and low-dose ketoconazole. N Engl J Med 2010;362:1846-1848.

36 Saveanu A, Gunz G, Guillen S, Dufour H, Culler MD, Jaquet P: Somatostatin and dopamine-somatostatin multiple ligands directed towards somatostatin and dopamine receptors in pituitary adenomas. Neuroendocrinology 2006;83:258-263.

-37 Bruns C, Lewis I, Briner U, Meno-Tetang G, Weckbecker G: SOM230: a novel somatostatin peptidomimetic with broad somatotropin release inhibiting factor (SRIF) receptor binding and a unique antisecretory profile. Eur J Endocrinol 2002;146:707-716.

- 38 Jaquet P, Gunz G, Saveanu A, Dufour H, Taylor J, Dong J, Kim S, Moreau JP, Enjalbert A, Culler MD: Efficacy of chimeric molecules directed towards multiple somatostatin and dopamine receptors on inhibition of $\mathrm{GH}$ and prolactin secretion from GH-secreting pituitary adenomas classified as partially responsive to somatostatin analog therapy. Eur J Endocrinol 2005;153:135-141.

>39 Ren SG, Taylor J, Dong J, Yu R, Culler MD, Melmed S: Functional association of somatostatin receptor subtypes 2 and 5 in inhibiting human growth hormone secretion. J Clin Endocrinol Metab 2003;88:4239-4245. 